\title{
Efficient production of (S)-1-phenyl-1, 2-ethanediol using xylan as co-substrate by a coupled multi- enzyme Escherichia coli system
}

\section{Junchao Rao}

Jiangnan University

\section{Rongzhen Zhang ( $\sim$ rzzhang666@aliyun.com )}

China pharmaceutical University https://orcid.org/0000-0001-6078-0174

\section{Guanyu Xu}

Beijing Institure of Technology

\section{Lihong Li}

Jiangnan University

\section{Yan Xu}

Jiangnan University

\section{Research}

Keywords: (S)-carbonyl reductase Il; glucose dehydrogenase mutant Ala258Phe; endo- $\beta-1,4-x y l a n a s e ~ 2$; multi-enzyme system; cofactor regeneration; chiral synthesis

Posted Date: March 26th, 2020

DOI: https://doi.org/10.21203/rs.2.21069/v2

License: (9) (1) This work is licensed under a Creative Commons Attribution 4.0 International License. Read Full License

Version of Record: A version of this preprint was published at Microbial Cell Factories on April 7th, 2020. See the published version at https://doi.org/10.1186/s12934-020-01344-x. 


\section{Abstract}

Background: ( $\mathrm{S}$ )-1-phenyl-1,2-ethanediol is an important chiral intermediate in the synthesis of liquid crystals and chiral biphosphines.(S)-carbonyl reductase II from Candida parapsilosis catalyzes the conversion of 2-hydroxyacetophenone to ( S )-1-phenyl-1,2-ethanediol with NADPH as a cofactor. Glucose dehydrogenase with a Ala258Phe mutation is able to catalyze the oxidation of xylose with concomitant reduction of NADP + to NADPH, while endo- $\beta-1,4-x y$ lanase 2 catalyzes the conversion of xylan to xylose. In the present work, the Ala258Phe glucose dehydrogenase mutant and endo- $\beta-1,4-x y l a n a s e ~ 2$ were introduced into the ( $S$ )-carbonyl reductase II-mediated chiral pathway to strengthen cofactor regeneration by using xylan as a naturally abundant co-substrate. Results: We constructed several coupled multi-enzyme systems by introducing ( $S$ )-carbonyl reductase II, the A258F glucose dehydrogenase mutant and endo- $\beta-1,4$-xylanase 2 into Escherichia coli . Different strains were produced by altering the location of the encoding genes on the plasmid. Only recombinant E. coli /pET-G-S-2 expressed all three enzymes, and this strain produced ( S )-1-phenyl-1,2-ethanediol from 2hydroxyacetophenone as a substrate and xylan as a co-substrate. The optical purity was $100 \%$ and the yield was $98.3 \%(6 \mathrm{~g} / \mathrm{L} 2-\mathrm{HAP})$ under optimal conditions of $35^{\circ} \mathrm{C}$, pH 6.5 and a 2:1 substrate-co-substrate ratio. The introduction of $A 258 \mathrm{~F}$ glucose dehydrogenase and endo- $\beta-1,4-x y$ lanase 2 into the ( $\mathrm{S}$ )-carbonyl reductase II-mediated chiral pathway caused a $54.6 \%$ increase in yield, and simultaneously reduced the reaction time from $48 \mathrm{~h}$ to $28 \mathrm{~h}$. Conclusions: This study demonstrates efficient chiral synthesis using a pentose as a co-substrate to enhance cofactor regeneration. This provides a new approach for enantiomeric catalysis through the inclusion of naturally abundant materials.

\section{Background}

Optically active alcohols are versatile chiral compounds, widely utilized as intermediates in the fine chemical and pharmaceutical industries [1-3]. Alcohol dehydrogenase-mediated asymmetric reduction of ketones is the most efficient method for synthesis of chiral alcohols, with a theoretical yield of $100 \%$ [ 5]. As an example, NADPH-dependent (S)-carbonyl reductase II (SCRII) from Candida parapsilosis CCTCC M203011 catalyzes the reduction of 2-hydroxyacetophenone (2-HAP) to (S)-1-phenyl-1,2-ethanediol (PED), an important chiral compound which can undergo stereoselective polymerization to form liquid crystals and chiral biphosphines [6, 7]. Cui et al. found that two new carbonyl reductases, 2,3-butanediol dehydrogenase from Bacillus subtilis and polyol dehydrogenase from Gluconobacter oxydans could convert 2-hydroxyacetophenon (2-HAP) to ( $R$ )-1-phenyl-1,2-ethanediol (( $R)$-PED) and (S)-1-phenyl-1,2ethanediol ((S)-PED) with excellent stereochemical selectivity and strong substrate tolerance, respectively [8].

The reaction that is catalyzed by alcohol dehydrogenase is limited by cofactor recycling. To enhance the regeneration of cofactors, substrate-coupled and enzyme-coupled techniques are always included in chiral synthesis reactions, through the use of multi-enzyme systems [9, 10]. For example, Xu et al. described the preparation of ethyl (S)-4-chloro-3-hydroxybutanoate via the coupling of carbonyl reductase with mannitol or sorbitol dehydrogenase [11]. Kosjek et al. carried out asymmetric synthesis of 4,4- 
dimethoxytetrahydro-2H-pyran-3-ol using a ketone reductase and in situ cofactor recycling by glucose dehydrogenase (GDH) [12]. Yamamoto et al. reported the efficient production of ethyl (S)-4-chloro-3hydroxybutanoate with over $99 \%$ optical purity by co-expressing carbonyl reductase from Kluyveromyces aestuarii and formate dehydrogenase in Escherichia coli [13]. Zhang et al. increased the production efficiency of (R)-PED by employing an enzyme-coupling system containing SCRII and GDH [14]. These systems enabled scientists to improve the efficiency of the enantioselective reaction with glucose or formate as co-substrates. However, the use of xylan in chiral synthesis to enhance cofactor recycling would be more interesting since they are naturally abundant materials.

Lignocellulose is well known as the most widely distributed and abundant polysaccharide in nature, which has been recognized as an attractive feedstock for the production of fuels and industrially important metabolites $[15,16]$. Lignocellulosic biomass is mainly composed of cellulose, hemicellulose, and lignin [17]. Pretreatment with alkaline, acidic, and/or enzymatic hydrolysis causes hemicellulose to decompose to pentoses, mainly xylan and lignin $[18,19]$. Xylan can be broken down to xylose by endo$\beta-1,4$-xylanases (XYN2), and the expression and characterization of XYN2 from Trichoderma reesei Rut C$30 \mathrm{~h}$ has been reported [20].

We have previously isolated a GDH with good solvent-resistant from Bacillus sp.YX-1, and introduced this enzyme for cofactor regeneration in chiral synthesis with glucose as a co-substrate [21]. The Ala258Phe mutant of GDH exhibited altered cofactor preference and improved xylose binding ability while reducing $\mathrm{NADP}^{+}$to NADPH [22]. An SCRII from C. parapsilosis has been shown to catalyze the conversion of 2HAP to (S)-PED with NADPH as an electron donor [23]. The present study aimed to improve the efficiency of chiral synthesis by the construction of an NADPH-recycling multi-enzyme system containing SCRII, A258F/GDH and XYN2 from T. reesei Rut C-30h (Fig. 1). XYN2 and A258F/GDH were introduced into the SCRII-mediated chiral synthesis pathway. In conditions of optimal pH, temperature and substrate-cosubstrate ratio, the E. coli/pET-G-S-2 system performed well in terms of (S)-PED production without the addition of external cofactors. This work thus presents a novel strategy for cofactor recycling by introducing xylan into an enantioselective reaction pathway, which offers efficient chiral synthesis using an abundant natural chemical as a co-substrate.

\section{Results And Discussion}

\section{Construction of the multi-enzyme-coupled-system containing SCRII, A258F/GDH and XYN2}

We successfully constructed four recombinant plasmids pET-S-2-G, pET-S-G-2, pET-G-2-S and pET-G-S-2 (Fig. 2), in which the three genes were located in different sites of the pET-28a plasmid. For example, SCRII was located nearest to and A258F/GDH farthest from the promoter, while XYN2 was located between SCRII and A258F/GDH in pET-S-2-G. Transformation into E. coli BL21 (DE3) competent cells resulted in the generation of E. coli/pET-S-2-G, E. coli/pET-S-G-2, E. coli/pET-G-2-S and E. coli/pET-G-S-2 strains, which were verified by DNA sequencing. 


\section{All three enzymes were successfully expressed in E. coli/pET-G-S-2 with no effect on cell growth}

Sodium dodecyl sulfate polyacrylamide gel electrophoresis (SDS-PAGE) analysis revealed that three predominant bands corresponding to the theoretical sizes $(33,30$ and $22 \mathrm{kDa}$ ) of the target recombinant enzymes (SCRII, A258F/GDH and XYN2, respectively) were only present in the cell-free extracts of $E$. coli/pET-G-S-2. However, no expression of A258F/GDH was observed in E. coli/pET-S-2-G or E. coli/pET-SG-2and SCRII could not be expressed in E. coli/pET-G-2-S (Fig. 3). The A258F/GDH and SCRIl enzymes were not able to be expressed in E. coli/pET-S-2-G, E. coli/pET-S-G-2 or E. coli/pET-G-2-S, which might be due to their location on the plasmid or their distance from the promoter. Kim et al. reported that the genes at the back of the promoter are expressed at lower levels than those at the front [24], indicating that protein expression levels are significantly influenced by the order of their coding genes on the plasmid. Moreover, the SD-AS sequence initiates translation, which might contribute to the differential expression of SCRII, A258F/GDH and XYN2 in E. coli [25].

Turbidity measurements revealed that E. coli/pET-G-S-2, E. coli/pET-SCRII, E. coli/pET-A258F/GDH, $E$. coli/pET-XYN2 and the control strain E. coli/pET-28a all had similar growth trends (Fig. 4). This suggests that the expression of A258F/GDH and XYN2 in E. coli does not affect cell growth. Therefore, we used $E$. coli/pET-G-S-2 expressing SCRII, A258F/GDH and XYN2 for further experiments and chiral synthesis.

\section{The functions of SCRII and A258F/GDH are well balanced}

The activities of all three enzymes in the cell-free extracts of recombinant strains are summarized in Table 2. The activities of SCRII, A258F/GDH and XYN2 from E. coli/pET-G-S-2 were found to be $0.85,1.36$ and $55.33 \mathrm{U} / \mathrm{mg}$ toward 2-HAP, xylose and xylan, respectively. The activities toward 2-HAP, xylose and xylan of $E$. coli/pET-G-S-2, which expressed all three enzymes, was lower than that of $E$. coli/pET-SCRII, $E$. coli/pET-A258F/GDH and E. coli/pET-XYN2, which only expressed (Table 2). The activity of XYN2 from $E$. coli/pET-XYN2 toward xylan was much higher than that of SCRII from E. coli/pET-SCRII or A258F/GDH from E. coli/pET-A258F/GDH, although SCRII and A258F/GDH exhibited similar activity toward their corresponding substrates. These results suggest that the functions of SCRII for chiral catalysis and GDH for cofactor regeneration are balanced.

Analysis of the activities of SCRII, A258F/GDH and XYN2 in E. coli/pET-G-S-2 were evaluated under different conditions, which revealed the optimum $\mathrm{pH}$ to be $6.5,6.5$ and 5.0 and the optimal temperature to be 35,50 and $50^{\circ} \mathrm{C}$ for SCRII, A258F/GDH and XYN2, respectively. Under the optimal conditions, the activities of SCRII, A258F/GDH and XYN2 in E. coli/pET-G-S-2 were 2.73, 6.85 and $267.51 \mathrm{U} / \mathrm{mg}$.

The activities of all three enzymes could be detected only in E. coli/pET-G-S-2, which also confirmed that the three enzymes were all expressed only in E. coli/pET-G-S-2. This may be due to the enzyme activity of A258F/GDH was higher than that of SCRII when expressed alone, and the difference was caused by the different positions of SCRII and A258F/GDH on the vector. In the recombinant strain E. coli/pET-G-S-2, the enzyme activity of SCRII was similar to that of A258F/GDH, while the three enzymes could not be all expressed in the other recombinant strains. As a result, the function of target enzymes SCRII and 
A258F/GDH in recombinant E. coli/pET-S-G-2 was more balanced than that in the other three recombinant strains E. coli/pET-S-G-2, E. coli/pET-S-2-G and E. coli/pET-G-S-2 [14].

Table 2. Enzyme activities in the cell-free extracts of recombinant strains.

\begin{tabular}{|c|c|c|c|}
\hline \multirow[t]{2}{*}{ Strains } & \multicolumn{3}{|c|}{ Specific activities (U/mg) } \\
\hline & Towards 2-HAP & Towards xylose & Towards xylan \\
\hline E. coli BL21/ pET-SCRII & $2.73 \pm 0.01$ & $\mathrm{ND}^{\mathrm{a}}$ & ND \\
\hline E. coli BL21/ pET-A258F/GDH & ND & $6.85 \pm 0.02$ & ND \\
\hline E. coli BL21/ pET-XYN2 & ND & ND & $267.51 \pm 11.8$ \\
\hline E. coli BL21/ pET-S-G-2 & $1.54 \pm 0.01$ & ND & $65.13 \pm 2.2$ \\
\hline E. coli BL21/ pET-S-2-G & $1.28 \pm 0.02$ & ND & $54.45 \pm 3.1$ \\
\hline E. coli BL21/ pET-G-S-2 & $0.85 \pm 0.02$ & $1.36 \pm 0.01$ & $55.33 \pm 4.3$ \\
\hline E. coli BL21/ pET-G-2-S & ND & $1.18 \pm 0.02$ & $35.93 \pm 2.6$ \\
\hline
\end{tabular}

Notes: ND, not detected.

\section{Optimization of biotransformation of (S)-PED by E. coli/pET-G-S-2}

Since the optimal temperature and $\mathrm{pH}$ conditions were different for each enzyme, the conditions for biotransformation of 2-HAP to (S)-PED by E. coli/pET-G-S-2 required further optimization. When the cell concentration was $10 \%(\mathrm{w} / \mathrm{v})$, the yield of $(S)$-PED from $6 \mathrm{~g} / \mathrm{L} 2$-HAP reached $85.8 \%$ in $24 \mathrm{~h}$ using $E$. coli/pET-G-S-2, while the yield from E. coli/pET-SCRII was only $63.6 \%$ at $24 \mathrm{~h}$ [23].

Phillips et al. reported the significant effect of $\mathrm{pH}$ on the enantiospecificity of a secondary alcohol dehydrogenase, and demonstrated that the $\mathrm{pH}$ affects the enzyme-substrate binding strength [26]. As depicted in Fig. 5a, the present study revealed that the yield of (S)-PED from E. coli/pET-G-S-2 was increased with the increased $\mathrm{pH}$ value between 3.0 and 6.5. At the optimal $\mathrm{pH}$ of 6.5 , biotransformation of (S)-PED was achieved with an optical purity of $100 \%$ and a yield of $90.5 \%$ when $6 \mathrm{~g} / \mathrm{L} 2$-HAP was used as substrate (Fig. 5a).

Temperature also has a significant influence on enzyme activity [27], and can affect product stereoselectivity during enzyme-catalyzed chiral biosynthesis [28]. As shown in Fig. 5b, we found that the optimal temperature for the biotransformation of (S)-PED by E. coli/pET-G-S-2 was $35^{\circ} \mathrm{C}$, at which the 
optical purity was $100 \%$ and the yield was $93.6 \%$ when the substrate 2 -HAP was $6 \mathrm{~g} / \mathrm{L}$. The optimal temperature of E. coli/pET-SCRII has been reported to be $35^{\circ} \mathrm{C}$ [23], while E. coli/pET-A258F/GDH exhibited the highest activity toward xylose at $55^{\circ} \mathrm{C}$ [22] and the optimal temperature for the activity of XYN2/E. coli toward xylan has been shown to be $50^{\circ} \mathrm{C}$ [20]. In the present study, we found the activity of SCRII to decrease rapidly with increasing temperature, while the activity of other two enzymes $\mathrm{A} 258 \mathrm{~F} / \mathrm{GDH}$ and $\mathrm{XYN} 2$ remained active at $35^{\circ} \mathrm{C}$.

Cai et al. described the impact of different substrate-co-substrate ratios on the biotransformation efficiency of recombinant enzymes [29]. Although we found SCRII and A258F/GDH from E. coli/pET-G-S-2 to had similar activities ( 0.85 and $1.36 \mathrm{U} / \mathrm{mg}$, respectively), XYN2 exhibited considerably higher activity of $55.33 \mathrm{U} / \mathrm{mg}$. Therefore, we optimized the ratio of substrate (2-HAP) and co-substrate xylan. As illustrated in Fig. 6, when the ratio of 2-HAP and xylan was 2:1, E. coli/pET-G-S-2 catalyzed the biotransformation of (S)-PED with the highest optical purity (100\%) and yield (95.8\%) with $6 \mathrm{~g} / \mathrm{L} 2$-HAP as substrate in $24 \mathrm{~h}$.

Both temperature and $\mathrm{pH}$ could affect the yield and optical purity of asymmetric reduction reactions [2628], while SCRII was an enzyme with unusual stereospecificity catalyzing an anti-Prelog reduction of 2HAP to (S)-PED [6]. Therefore, through the optimization of asymmetric reduction reaction conditions, the temperature and $\mathrm{pH}$ had a great influence on the yield and hardly affected the optical purity.

As a control, we also investigated the biosynthesis of (S)-PED by recombinant strains $E$. coli/pET-S-G-2, $E$. coli/pET-G-2-S and E. coli/pET-S-2-G under optimal reaction conditions. However, we did not detect the production of (S)-PED in $24 \mathrm{~h}$ by E. coli/pET-G-2-S. The recombinant E. coli/pET-S-G-2 and E. coli/pET-S-2$\mathrm{G}$ synthesize (S)-PED in a slightly lower yield in $24 \mathrm{~h}$ than E. coli/pET-SCRII.

\section{Efficient transformation of (S)-PED by E. coli/pET-G-S-2}

We investigated the reaction duration of the enzyme-coupled system E. coli/pET-G-S-2 by targeting the highest optical purity and yield of (S)-PED under optimal conditions of $\mathrm{pH}$, temperature and substrate-cosubstrate ratio. The yield of (S)-PED was highest (98.3\%) with an optical purity of $100 \%$ at $28 \mathrm{~h}$ when the substrate 2-HAP was $6 \mathrm{~g} / \mathrm{L}$ (Fig. 7). Compared with E. coli/pET-SCRII, the introduction of XYN2 and A258F/GDH into the SCRII-mediated chiral synthesis pathway in E. coli/pET-G-S-2 caused a $54.6 \%$ increase in yield and the time required for the reaction to complete was significantly reduced from $48 \mathrm{~h}$ to $28 \mathrm{~h}$ [23]. The results of the present study suggest that the introduction of XYN2 and A258F/GDH accelerates the bioconversion of 2-HAP to (S)-PED in SCRII-mediated chiral synthesis. Efficiently catalysis of (S)-PED biosynthesis with absolute stereochemical selectivity (100\% optical purity) was achieved using E. coli/pET-G-S-2. Furthermore, biotransformation of (S)-PED by E. coli/pET-G-S-2 was upscaled in $200 \mathrm{ml}$. It produced (S)-PED with an optical purity of $>99.9 \%$ and a yield of $96.8 \%$ when $6 \mathrm{~g} / \mathrm{L} 2$-HAP was used as substrate. Thus, the multi-enzyme-coupled system E. coli/pET-G-S-2 efficiently catalyzes the stereospecific reduction of 2-HAP to (S)-PED. Ye et al. reported the improved efficiency of ethyl (S)-4chloro-3-hydroxybutanoate synthesis through the coupling of carbonyl reductase and GDH [30]. Kosjek et al. performed asymmetric synthesis of 4,4-dimethoxytetrahydro-2H-pyran-3-ol by co-expressing a ketone reductase and glucose dehydrogenase [12]. These approaches both achieved increased cofactor 
regeneration, which could overcome the limitation of coenzyme restriction for asymmetric synthesis and accelerate the initial reaction rate, resulting in improved catalytic efficiency. The present work describes a simple approach to achieve cofactor regeneration in chiral synthesis using a naturally abundant cosubstrate.

\section{Conclusions}

To improve the efficiency of chiral synthesis, A258F/GDH and XYN2-mediated cofactor regeneration were introduced into the SCRII-catalyzed chiral synthesis pathway. Several multi-enzyme-coupled systems containing SCRII, A258F/GDH and XYN2 were constructed by changing the gene locations within the plasmid. The three enzymes were all successfully expressed in the recombinant strain, E. coli/pET-G-S-2. The biotransformation of 2-HAP to (S)-PED was achieved with a high optical purity (100\%) in a high yield (98.3\%) with $6 \mathrm{~g} / \mathrm{L} 2-\mathrm{HAP}$ in $28 \mathrm{~h}$. The introduction of XYN2 and A258F/GDH into the asymmetric reaction dramatically improved the efficiency of chiral biosynthesis. This work provides a foundation for future studies of efficient enantioselective synthesis using an abundant natural compound, xylan, as a co-substrate to enhance cofactor recycling.

\section{Materials And Methods}

\section{Microorganisms and chemicals}

The PrimeSTAR $® M A X$, pMD19-T vector, restriction enzymes and T4 DNA ligase were bought from Takara (Shanghai, China). 2-HAP was purchased from TCl Development Co., Ltd. (Shanghai, China). (R)-, (S)-PED, PED and NADPH were purchased from Sigma-Aldrich (Shanghai, China). Hexane and isopropanol of chromatographic grade used for high performance liquid chromatography (HPLC) were purchased from Sigma-Aldrich (Shanghai, China). All other chemicals used were of analytical grade and commercially available.

Escherichia coli JM109 (Invitrogen Co., Shanghai, China) was used as a host for plasmid propagation. E. coli BL21 (DE3) (Invitrogen Co., Shanghai, China) was used for protein expression. E. coli JM109 and E. coli BL21 were cultured at $37^{\circ} \mathrm{C}$ in Luria-Bertani (LB) medium supplemented with kanamycin (50

$\mu \mathrm{g} / \mathrm{mL}$ ) as the selective marker. The strains and plasmids used in this work were summarized in Table 1.

Table 1. Bacterial strains, plasmids and primers used in this work. 


\begin{tabular}{|c|c|c|}
\hline Strains/plasmids/primers & Characteristics & Sources \\
\hline \multicolumn{3}{|l|}{ Strains } \\
\hline E. coli JM109 & Host gene cloning & Invitrogen \\
\hline E. coli BL21(DE3) & Host of target gene for expression & Invitrogen \\
\hline E. coli/pET-A258F/GDH & E. coli BL21 containing pET-A258F/GDH & [22] \\
\hline E. coli/pET-SCRII & E. coli BL21 containing pET-SCRII & [23] \\
\hline E. coli/pET-XYN2 & E. coli BL21 containing pET-XYN2 & This work \\
\hline E. coli/pET-S-G-2 & E. coli BL21 containing pET-S-G-2 & This work \\
\hline E. coli/pET-S-2-G & E. coli BL21 containing pET-S-2-G & This work \\
\hline E. coli/pET-G-S-2 & E. coli BL21 containing pET-G-S-2 & This work \\
\hline E. coli/pET-G-2-S & E. coli BL21 containing pET-G-2-S & This work \\
\hline \multicolumn{3}{|l|}{ Plasmids } \\
\hline pET-A258F/GDH & A258F/GDH gene on pET-28a, $6.15 \mathrm{~kb}$ & This lab \\
\hline pET-SCRII & SCRII gene on pET-28a, $6.21 \mathrm{~kb}$ & This lab \\
\hline pET-XYN2 & XYN2 gene on pET-28a, $6.04 \mathrm{~kb}$ & This work \\
\hline pMD19-T & Cloning plasmid, $2.7 \mathrm{~kb}, \mathrm{Amp}^{\mathrm{r}}$ & Takara Co. \\
\hline T-S-G-2 & S-G-2 gene on pMD19-T,4.97 kb & This work \\
\hline T-S-2-G & S-2-G gene on pMD19-T, $4.97 \mathrm{~kb}$ & This work \\
\hline T-G-S-2 & G-S-2 gene on pMD19-T, $4.97 \mathrm{~kb}$ & This work \\
\hline T-G-2-S & G-2-S gene on pMD19-T, $4.97 \mathrm{~kb}$ & This work \\
\hline pET-S-G-2 & S-G-2 gene on pET-28a $7.66 \mathrm{~kb}$ & This work \\
\hline pET-S-2-G & S-2-G gene on pET-28a, $7.66 \mathrm{~kb}$ & This work \\
\hline pET-G-S-2 & G-S-2 gene on pET-28a, $7.66 \mathrm{~kb}$ & This work \\
\hline pET-G-2-S & G-2-S gene on pET-28a, $7.66 \mathrm{~kb}$ & This work \\
\hline Primers & Sequence $\left(5^{\prime} \rightarrow 3^{\prime}\right)$ & \\
\hline SCRII-F $F_{1}$ & \multicolumn{2}{|c|}{ GGATCCATGGGCGAAATCGAATCTTATTGCAA } \\
\hline SCRII-F $F_{2}$ & \multicolumn{2}{|c|}{ TGGCCGCGGTGAAGGAGATATACCATGGGCGAAATCGAATCTTA } \\
\hline SCRII-F 3 & \multicolumn{2}{|c|}{ TACCGTGAGCGAAGGAGATATACCATGGGCGAAATCGAATCTTA } \\
\hline $\mathrm{SCRII}_{-} \mathrm{R}_{1}$ & \multicolumn{2}{|c|}{ AACTCACCATGGTATATCTCCTTCTGGACAAGTGTAACCACCATCG } \\
\hline SCRII-R $R_{2}$ & \multicolumn{2}{|c|}{ CCGGATACATGGTATATCTCCTTCTGGACAAGTGTAACCACCATCG } \\
\hline $\mathrm{SCRII}_{3} \mathrm{R}_{3}$ & \multicolumn{2}{|c|}{ TGGTCTGCATGGTATATCTCCTTCTGGACAAGTGTAACCACCATCG } \\
\hline $\mathrm{SCRII}_{-} \mathrm{R}_{4}$ & \multicolumn{2}{|c|}{ GAGCTCTGGACAAGTGTAACCACCATCG } \\
\hline A258F/GDH-F ${ }_{1}$ & \multicolumn{2}{|c|}{ TACCGTGAGCGAAGGAGATATACCATGTATCCGGATTTAAAAGG } \\
\hline $\mathrm{A} 258 \mathrm{~F} / \mathrm{GDH}-\mathrm{F}_{2}$ & \multicolumn{2}{|c|}{ CACTTGTCCAGAAGGAGATATACCATGTATCCGGATTTAAAAGG } \\
\hline $\mathrm{A} 258 \mathrm{~F} / \mathrm{GDH}-\mathrm{F}_{3}$ & \multicolumn{2}{|c|}{ GGATCCATGTATCCGGATTTAAAAGG } \\
\hline $\mathrm{A} 258 \mathrm{~F} / \mathrm{GDH}-\mathrm{R}_{1}$ & \multicolumn{2}{|c|}{ GAGCTCACCGCGGCCAAACTGGAATG } \\
\hline $\mathrm{A} 258 \mathrm{~F} / \mathrm{GDH}-\mathrm{R}_{2}$ & \multicolumn{2}{|c|}{ TGGTCTGCATGGTATATCTCCTTCACCGCGGCCAAACTGGAATG } \\
\hline $\mathrm{A} 258 \mathrm{~F} / \mathrm{GDH}-\mathrm{R}_{3}$ & \multicolumn{2}{|c|}{ TTTCGCCCATGGTATATCTCCTTCACCGCGGCCAAACTGGAATG } \\
\hline $\mathrm{XYN} 2-\mathrm{F}_{1}$ & \multicolumn{2}{|c|}{ CACTTGTCCAGAAGGAGATATACCATGCAGACCATCCAGCCGGG } \\
\hline $\mathrm{XYN} 2-\mathrm{F}_{2}$ & \multicolumn{2}{|c|}{ TGGCCGCGGTGAAGGAGATATACCATGCAGACCATCCAGCCGGG } \\
\hline $\mathrm{XYN} 2-\mathrm{F}_{3}$ & \multicolumn{2}{|c|}{ CACTTGTCCAGAAGGAGATATACCATGCAGACCATCCAGCCGGG } \\
\hline $\mathrm{XYN} 2-\mathrm{R}_{1}$ & \multicolumn{2}{|c|}{ CCGGATACATGGTATATCTCCTTCGCTCACGGTAATGCTGGCGC } \\
\hline $\mathrm{XYN} 2-\mathrm{R}_{2}$ & \multicolumn{2}{|c|}{ TTTCGCCCATGGTATATCTCCTTCGCTCACGGTAATGCTGGCGC } \\
\hline $\mathrm{XYN}_{2}-\mathrm{R}_{3}$ & \multicolumn{2}{|c|}{ GAGCTCGCTCACGGTAATGCTGGCGC } \\
\hline
\end{tabular}

Notes: $\mathrm{Ap}^{\mathrm{r}}$ : ampicillin resistance.

The sequence of SD-AS is bold; the restriction endonuclease sites are underlined.

\section{Gene cloning of SCRII, A258F/GDH and XYN2}

The oligonucleotide primers (Table 1) were designed based on the gene sequences. The genes SCRII, A258F/GDH and XYN2 were amplified using the plasmids pET-SCRII, pET-A258F/GDH and pET-XYN2 as the DNA template, respectively. The PCR-amplified products were ligated to pMD19-T (Takara-Bio, Kyoto, Japan) to obtain T-SCRII, T-A258F/GDH and T-XYN2 plasmids, which were transformed in E. coli JM109 cells and the recombinant strains were verified by DNA sequencing in Takara Co. (Shanghai, China). 


\section{Construction of co-expression system of SCRII, A258F/GDH and XYN2}

Several multi-enzymes coupled systems containing the SCRII, XYN2 and A258F/GDH were constructed using a Shine-Dalgarno (SD) and aligned spacing (AS) sequence (GAAGGAGATATACC) linker between them. Either SCRII or A258F/GDH was nearest to the promoter. The fusion genes SCRII-SD-ASA258F/GDH-SD-AS-XYN2 (named as S-G-2), SCRII-SD-AS-XYN2-SD-AS-A258F/GDH (named as S-2-G), A258F/GDH-SD-AS-SCRII-SD-AS-XYN2 (named as G-S-2), A258F/GDH-SD-AS-XYN2-SD-AS-SCRII (named as G-2-S), were cloned using overlap-extension technique. In each fusion gene, the leftmost genes were nearest the promoter. Then the four fusion genes were constructed on the plasmid pET-28a, and the plasmids, pET-S-G-2, pET-S-2-G, pET-G-S-2 and pET-G-2-S were transformed into the competent cells of $E$. coli BL21. The corresponding recombinant strains E. coli/pET-S-G-2, E. colipET-S-2-G, E. colipET-G-S-2 and E. colipET-G-2-S were obtained after the confirmation of nucleotide sequencing. Meanwhile, the plasmids, pET-SCRII, pET-A258F/GDH, and pET-XYN2 were transformed into the competent cells of E. coli BL21 to obtain recombinant E. coli/pET-SCRII, E. coli/pET-A258F/GDH and E. coli/pET-XYN2.

\section{Protein expression}

The recombinant strains E. coli/pET-S-2-G, E. coli/pET-S-G-2, E. coli/pET-G-2-S and E. coli/pET-G-S-2 were cultured in LB medium containing $50 \mu \mathrm{g} / \mathrm{mL}$ kanamycin at $37^{\circ} \mathrm{C}$. When $O D_{600}$ value of the culture reached 0.8 , isopropyl- $\beta$-D-thiogalactopyranoside (IPTG) of $0.1 \mathrm{mM}$ was added to induce protein expression. The cultures were cultivated at $25^{\circ} \mathrm{C}$ for $16 \mathrm{~h}$. The cultures were harvested by centrifugation, suspended in $50 \mathrm{mM}$ Tris- $\mathrm{HCl}(\mathrm{pH} \mathrm{8.0)}$ and $150 \mathrm{mM} \mathrm{NaCl}$, and then disrupted with an ultrasonic oscillator (Insonater $201 \mathrm{M}$; Kubota, Japan). After centrifugation $(10,000 \times \mathrm{g})$ for $30 \mathrm{~min}$ at $4{ }^{\circ} \mathrm{C}$, the cellfree extracts were used for sodium dodecyl sulfate-polyacrylamide gel electrophoresis (SDS-PAGE) analysis and the enzyme assays.

\section{Enzyme assay}

The specific activities of three enzymes, SCRII, A258F/GDH and XYN2 were determined using cell-free extracts of recombinant E. coli/pET-G-S-2, E. coli/pET-G-2-S, E. coli/pET-S-G-2 and E. coli/pET-S-2-G. Their enzyme activities were analyzed using 2-HAP, xylose and xylan as substrates, respectively.

The enzymatic activities of SCRII for oxidation of 2-HAP were measured at $35^{\circ} \mathrm{C}$ and $\mathrm{pH} 6.5$ mixture by spectrophotometrically recording the rate of change of NADPH absorbance at $340 \mathrm{~nm}$. One unit of enzyme activity is defined as the amount of enzyme catalyzing the oxidation of $1 \mu \mathrm{mol}$ of NADPH per minute under the measurement conditions. The standard assays were performed as described by Zhang et al [23].

The oxidation activities of $\mathrm{A} 258 \mathrm{~F} / \mathrm{GDH}$ were measured at $35^{\circ} \mathrm{C}$ and $\mathrm{pH} 7.0$ by spectrophotometrically recording the rate of change of NADPH absorbance at $340 \mathrm{~nm}$. One unit of enzyme activity is defined as the amount of enzyme catalyzing the reduction of $1 \mu \mathrm{mol}$ of $\mathrm{NADP}^{+}$per minute under the measurement conditions. 
Xylanase activity was assayed by the method described by Bailey et al. with $1 \%$ oat-spelt xylan (Sigma) as substrate at $50^{\circ} \mathrm{C}$ [31]. Appropriate dilutions of the protein solution in $0.1 \mathrm{M}$ sodium citrate buffer $(\mathrm{pH}$ 6.0) were used as the enzyme source. The amount of released sugar was determined by the dinitrosalicylic acid method described by Miller et al. [32]. The protein concentration was determined by the Bradford method with bovine serum albumin as the standard.

The temperature optimum of enzymes activity was determined at various temperatures $\left(20-80^{\circ} \mathrm{C}\right)$. The $\mathrm{pH}$ optimum of enzyme activity was determined at the optimal temperature over a $\mathrm{pH}$ range of 3.0-10.0. The buffers used were $0.1 \mathrm{M}$ sodium citrate buffer ( $\mathrm{pH} 3.0$ to 6.5 ), $0.1 \mathrm{M}$ potassium phosphate buffer ( $\mathrm{pH}$ 6.5 to 7.5 ), and $0.1 \mathrm{M}$ Tris-HCl buffer (pH 8.0 to 10.0), respectively.

\section{Biotransformation and analytical methods}

The recombinant E. coli/pET-G-S-2 cells were used for 2-HAP biotransformation. The biotransformation was carried out as described previously with minor modifications [33]. The reaction mixture $(2 \mathrm{~mL})$ consisted of $0.1 \mathrm{M}$ sodium citrate buffer ( $\mathrm{pH} 6.5), 6 \mathrm{~g} / \mathrm{L} 2-\mathrm{HAP}, 6 \mathrm{~g} / \mathrm{L}$ xylan, and $0.2 \mathrm{~g}$ washed wet cells $(10 \% \mathrm{w} / \mathrm{v})$. When the reaction was upscaled in $200 \mathrm{~mL}$, the corresponding washed wet cells was $20 \mathrm{~g}$, and the other components in the reaction mixture maintained the same concentration. The reactions were carried out at $35^{\circ} \mathrm{C}$ for $24 \mathrm{~h}$ with shaking at $200 \mathrm{rpm}$, using the wet recombinant cells as biocatalysts. At the end of the reaction, the product (S)-PED was extracted with ethyl acetate, and the organic layer was used for analysis. The optical purity and yield of the product were determined by HPLC on a Chiralcel OB$\mathrm{H}$ column ( $4.6 \times 250 \mathrm{~mm}$ Daicel Chemical Ind. Ltd., Japan) with flow rate $0.5 \mathrm{~mL} / \mathrm{min}$ at $25^{\circ} \mathrm{C}$. The retention times of $(S)$-PED and 2-HAP are 11.5 and 17.8 minutes, respectively.

\section{$\mathrm{pH}$ and temperature dependence}

The effects of $\mathrm{pH}$ and reaction temperature on 2-HAP biotransformation were determined by the whole cells of E. coli/pET-G-S-2. The biotransformation of 2-HAP to (S)-PED was carried out in $\mathrm{pH} 3.0-10.0$ using $0.1 \mathrm{M}$ sodium citrate ( $\mathrm{pH} 3.0-6.5), 0.1 \mathrm{M}$ potassium phosphate $(\mathrm{pH} 6.5-7.5)$, and $0.1 \mathrm{mM}$ Tris-HCl (pH 8.0-10.0) as buffer. The temperature dependence of E. coli/pET-G-S-2 mediated 2-HAP transformation was determined at various temperatures ranging from 20 to $50^{\circ} \mathrm{C}$ under the optimal pH. The biotransformation of 2-HAP was determined with the standard assay method described above.

\section{Optimization of ratios of substrate and co-substrate}

Under the optimal $\mathrm{pH}$ and temperature, the biotransformation was explored by E. coli/pET-G-S-2 with the ratios of 2-HAP and xylan varying from 5:1 to 1:5. The effects of the ratios on the efficiency of 2-HAP transformation were configured with $6 \mathrm{~g} / \mathrm{L} 2$-HAP and 1.2, 2.0, 3.0, 6.0, 12.0, 18.0 or $30.0 \mathrm{~g} / \mathrm{L}$ xylan.

\section{Abbreviations}


GDH, glucose dehydrogenase; 2-HAP, 2-hydroxyacetophenone; SCRII, (S)-carbonyl reductase II; (S)-PED, (S)-1-phenyl-1, 2-ethanediol; XYN2, endo- $\beta-1,4$-xylanase 2

\section{Declarations}

\section{Authors' contributions}

JC Rao conceived and designed the study, conducted experiments, analyzed and interpreted data, and wrote the manuscript. RZ Zhang led the project and revised the manuscript. GY Xu and LH Li helped to analyze data and performed the calculation. $Y$ Xu revised the manuscript. All authors read and approved the final manuscript.

\section{Acknowledgments}

We thank Amy Phillips, PhD, from Liwen Bianji, Edanz Editing China (www.liwenbianji.cn/ac), for editing the English language of this manuscript.

\section{Competing interests}

The authors declare they have no competing interests.

\section{Availability of data and materials}

The datasets of supporting the conclusions in this article are included in the manuscript.

\section{Consent for publication}

Not applicable.

\section{Ethics approval and consent to participate}

Not applicable.

\section{Funding}

This project was supported by the National Key research and Development Program of China (2018YFA0900302), the National Science Foundation of China (31970045), the Program for Advanced Talents within Six Industries of Jiangsu Province (2015-SWYY-010), the National First-class Discipline Program of Light Industry Technology and Engineering (LITE2018-12), the Program of Introducing Talents of Discipline to Universities (111-2-06), and Top-notch Academic Programs Project of Jiangsu Higher Education Institutions.

\section{Publisher's Note:}


Springer Nature remains neutral with regard to jurisdictional claims in published maps and institutional affiliation.

\section{References}

1. Schoemaker HE, Daniel M, Wubbolts MG. Dispelling the myths--biocatalysis in industrial synthesis. Science, 2003. 299(5613): p. 1694-1697.

2. Torrelo G, Hanefeld U, Hollmann F. Biocatalysis. Catal Lett, 2015. 145(1): p. 309-345.

3. Lima-Ramos J, Neto W, Woodley JM. Engineering of biocatalysts and biocatalytic processes. Top Catal, 2014. 57(5): p. 301-320.

4. Yasohara Y, Kizaki N, Hasegawa J, Wada M, Kataoka M, Shimizu S. Molecular cloning and overexpression of the gene encoding an NADPH-dependent carbonyl reductase from Candida magnoliae, involved in stereoselective reduction of ethyl 4-chloro-3-oxobutanoate. Biosci Biotechnol Biochem, 2000. 64(7): p. 1430-1436.

5. Yu T, Li JF, Zhu LJ, Hu D, Deng C, Cai YT, Wu MC. Reduction of m-chlorophenacyl chloride coupled with regeneration of NADPH by recombinant Escherichia coli cells co-expressing both carbonyl reductase and glucose 1-dehydrogenase. Ann Microbiol, 2016. 66(1): p. 343-350.

6. Nie $Y, X u Y, M u X Q$, Wang HY, Yang M, Xiao R. Purification, characterization, gene cloning, and expression of a novel alcohol dehydrogenase with anti-prelog stereospecificity from Candida parapsilosis. Appl Environ Microbiol, 2007. 73(11): p. 3759-3764.

7. Zhang RZ, Zhu GY, Zhang WC, Cao S, Ou XJ, Li X, Bartlam M, Xu Y, Zhang XC, Rao ZH. Crystal structure of a carbonyl reductase from Candida parapsilosis with anti-Prelog stereospecificity. Protein Sci, 2008. 17(8): p. 1412-1423.

8. Cui ZM, Zhang JD, Fan XJ, Zheng GW, Chang HH, Wei WL. Highly efficient bioreduction of 2hydroxyacetophenone to $(S)$ - and $(R)$-1-phenyl-1,2-ethanediol by two substrate tolerance carbonyl reductases with cofactor regeneration. J Biotechnol, 2017. 243: p. 1-9.

9. Gröger H, Chamouleau F, Orologas N, Rollmann C, May O. Enantioselective reduction of ketones with "designer cells" at high substrate concentrations: highly efficient access to functionalized optically active alcohols. Angew Chem Int Ed, 2006. 45(34): p. 5677-5681.

10. Andre J, Radoslav M, Albert P, Fabrizio S, Ulrich S, Ansorge-Schumacher MB, Pablo-Domínguez DM. Asymmetric reduction of ketones with recombinant $E$. coli whole cells in neat substrates. Chem Commun, 2011. 47(44): p. 12230-12232.

11. Xu Q, Tao WY, Huang H, Li S. Highly efficient synthesis of ethyl (S)-4-chloro-3-hydroxybutanoate by a novel carbonyl reductase from Yarrowia lipolytica and using mannitol or sorbitol as cosubstrate. Biochem Eng J, 2016. 106: p. 61-67.

12. Kosjek B, Nti-Gyabaah J, Telari K, Dunne L, Moore J. Preparative asymmetric synthesis of 4,4Dimethoxytetrahydro-2H-pyran-3-ol with a ketone reductase and in situ cofactor recycling using 
glucose dehydrogenase. Org Process Res Dev, 2008. 12(4): p. 584-588.

13. Yamamoto H, Mitsuhashi K, Kimoto N, Kobayashi Y, Esaki N. Robust NADH-regenerator: improved alpha-haloketone-resistant formate dehydrogenase. Appl Microbiol Biotechnol, 2005. 67(1): p. 33-39.

14. Zhang RZ, Zhang BT, Xu Y, Li YH, Li M, Liang HB, Xiao R. Efficicent (R)-phenylethanol production with enantioselectivity-alerted (S)-carbonyl reductase II and NADPH regeneration. PLoS One, 2013. 8(12): p. e83586.

15. Kumar S, Gummadi SN. Metabolism of glucose and xylose as single and mixed feed in Debaryomyces nepalensis NCYC 3413: production of industrially important metabolites. Appl Microbiol Biotechnol, 2011. 89(5): p. 1405-1415.

16. Wei P, Lin M, Wang Z, Fu H, Yang H, Jiang W. Metabolic engineering of Propionibacterium freudenreichii subsp. shermanii for xylose fermentation. Bioresour Technol, 2016. 219: p. 91-97.

17. Zhang B, Sun H, Li J, Wan Y, Li Y, Zhang Y. High-titer-ethanol production from cellulosic hydrolysate by an engineered strain of Saccharomyces cerevisiae during an in situ removal process reducing the inhibition of ethanol on xylose metabolism. Process Biochem, 2016. 51(8):967-972.

18. Megawati, Sediawan WB, Sulistyo $H$, Hidayat M. Sulfuric acid hydrolysis of various lignocellulosic materials and its mixture in ethanol production. Biofuels, 2015. 6(5-6): p. 331-340.

19. Taherzadeh MJ, Karimi K. Acid-based hydrolysis processes for ethanol from lignocellulosic materials: A review. BioResources, 2007. 2(3):p. 472-499.

20. Jun H, Yu B, Zhang KY, Ding XM, Chen DW. Sequencing and expression of the xylanase gene 2 from Trichoderma reesei Rut C-30 and characterization of the recombinant enzyme and its activity on xylan. J Mol Microbiol. 2009. 17(3): p. 101-109.

21. Zhang BT, Zhang RZ, Wang $L$ and Xu Y. Gene cloning and characterization of a solvent-resistant glucose dehydrogenase from Bacillus sp.YX-1. Acta Microbiologica Sinica, 2013. 53(6): p. 561-568.

22. Li J, Zhang RZ, Xu Y, Xiao R, Li K, Liu HY. Ala258Phe substitution in Bacillus sp. YX-1 glucose dehydrogenase improves its substrate preference for xylose. Process Biochem, 2017. 56: p. 124-131.

23. Zhang RZ, Geng YW, Xu Y, Zhang WC, Wang SS, Xiao R. Carbonyl reductase SCRII from Candida parapsilosis catalyzes anti-Prelog reaction to $(S)$-1-phenyl-1,2-ethanediol with absolute stereochemical selectivity. Bioresour Technol, 2011. 102(2): p. 483-489.

24. Kim, KJ, Kim HE, Lee KH, Han W, Yi MJ, Jeong J, Oh BH. Two-promoter vector is highly efficient for overproduction of protein complexes. Protein Sci, 2004. 13(6): p. 1698-1703.

25. Ringquist S,Shinedling S, Barrick D, Green L, Binkley J, Stormo,GD, Gold L. Translation initiation in Escherichia coli: Sequences within the ribosome-binding site. Mol Microbiol, 1992. 6(9): p. 12191229.

26. Phillips R.S. Tailoring the substrate specificity of secondary alcohol dehydrogenase. Can J Chem, 2002. 80(6): p. 680-685.

27. 27. Daniel R, Peterson M, Danson M, Price N, Kelly S, Monk C. The molecular basis of the effect of temperature on enzyme activity. Biochem J, 2010. 425(2): p. 353-360. 
28. Zhang RZ, Xu Y, Sun Y, Zhang WC, Xiao R. Ser67Asp and His68Asp substitutions in candida parapsilosis carbonyl reductase alter the coenzyme specificity and enantioselectivity of ketone reduction. Appl Environ Microbiol, 2009. 75(7): p. 2176-2183.

29. Cai P, An M, Xu L, Xu S, Hao N, Li Y. Development of a substrate-coupled biocatalytic process driven by an NADPH-dependent sorbose reductase from Candida albicans for the asymmetric reduction of ethyl 4-chloro-3-oxobutanoate. Biotechnol Lett, 2012. 34(12): p. 2223-2227.

30. Ye Q, Cao H, Zang GL, Mi L, Yan M, Zhang YY, Li XM, Li JA, Xu L. Biocatalytic synthesis of (S)-4chloro-3-hydroxybutanoate ethyl ester using a recombinant whole-cell catalyst. Appl Microbiol Biotechnol, 2010. 88(6): p. 1277-1285.

31. Bailey MJ, Biely P, and Poutanen K. Interlabortory testing of methods for assay of xylanase activity. J Biotechnol, 1992. 23(3): p. 257-270.

32. Miller GL, Blum R, Glennon WE. Burton A.L. Measurement of carboxymethylcellulase activity. Anal Biochem, 1960. 1(2): p. 127-132.

33. Zhang RZ, Xu Y, Xiao R, Wang SS, Zhang BT. Improved production of ( $R$ )-1-phenyl-1,2-ethanediol using Candida parapsilosis $(R)$-carbonyl reductase expressed in Pichia pastoris. Process Biochem, 2011. 46(3): p. 709-713.

\section{Figures}




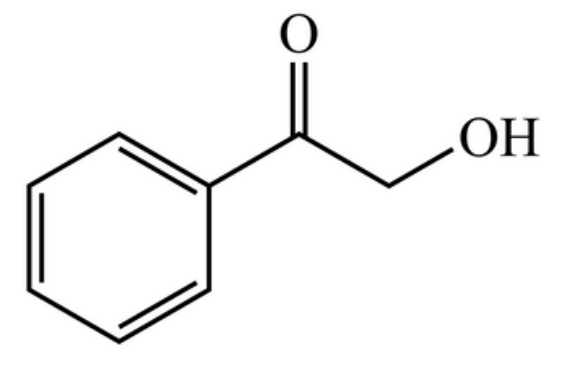

2-HAP

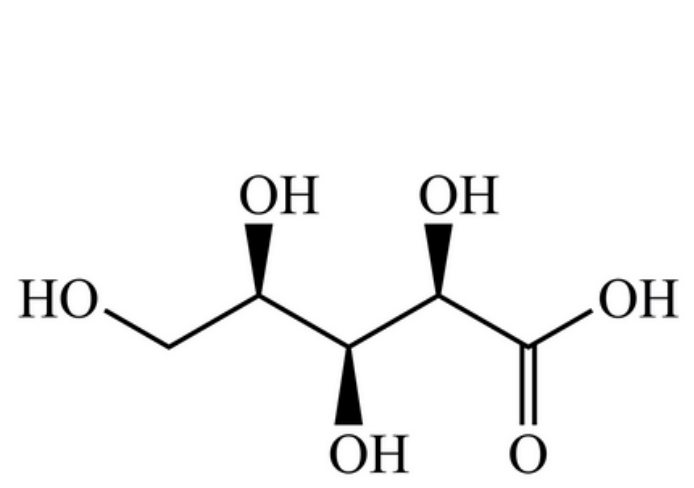

D-xylonic acid
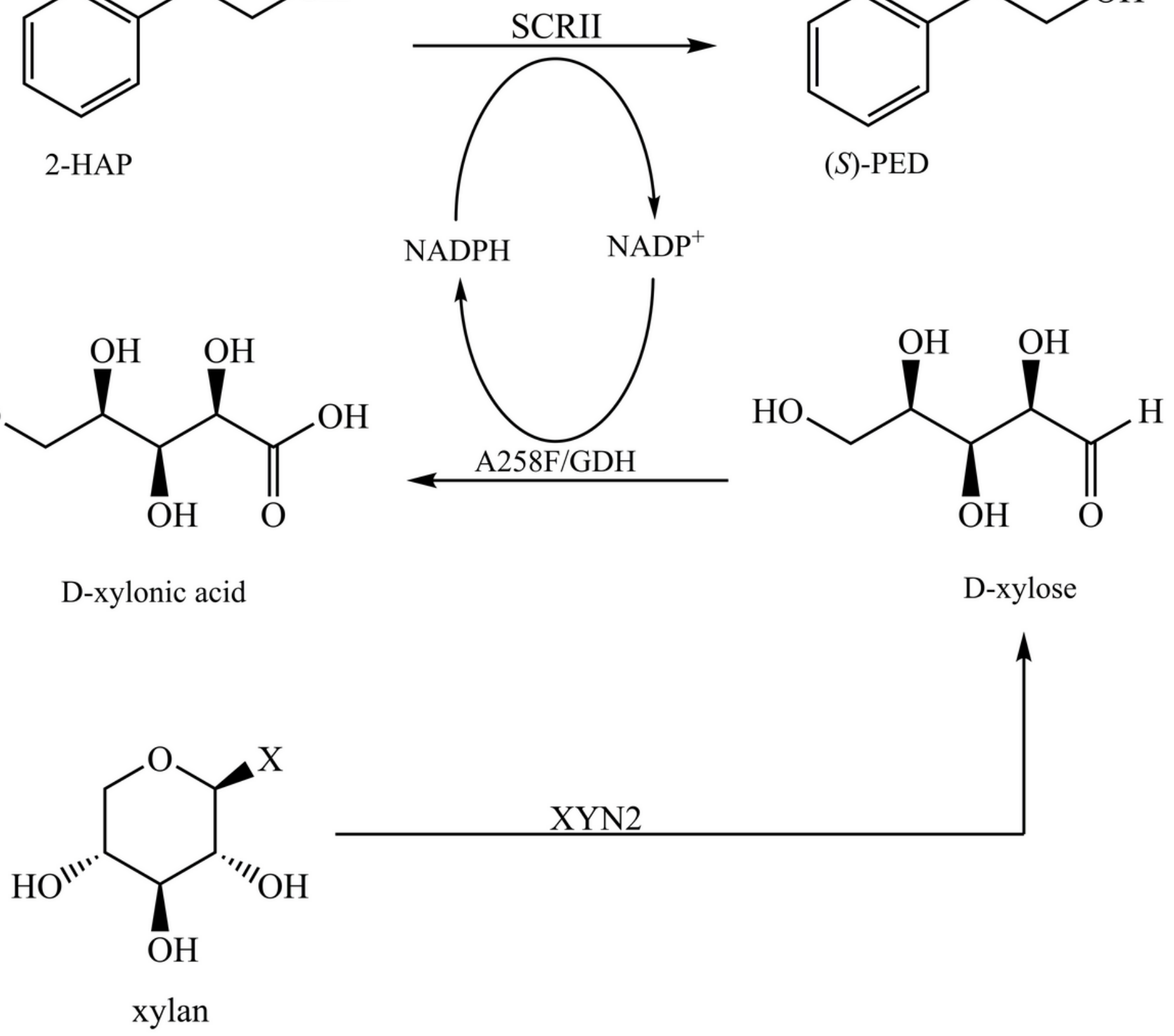

xylan

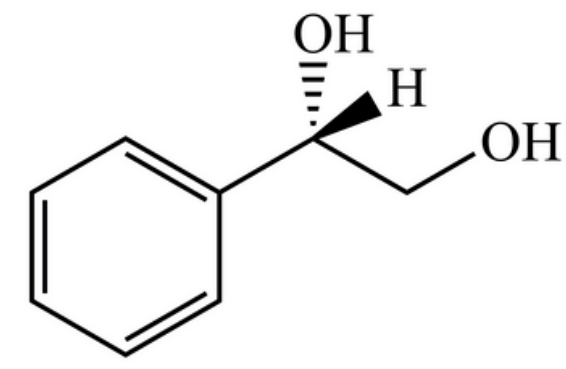

$(S)$-PED

\section{XYN2}

D-xylose

Figure 1

The biosynthetic pathway of (S)-PED through a multi-enzyme coupled system containing SCRII, A258F/GDH, and XYN2. 

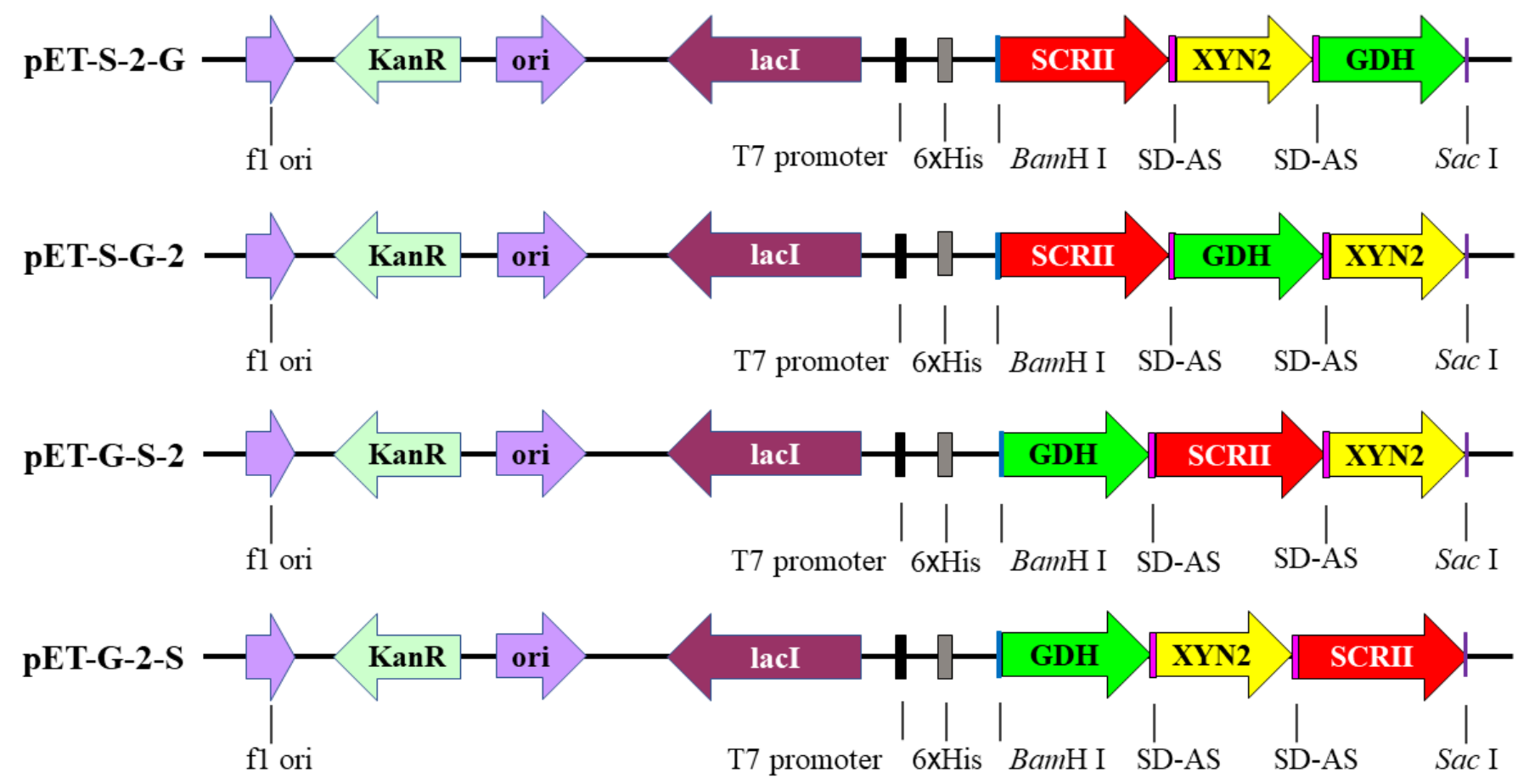

\section{Figure 2}

The location of SCRII, A258F/GDH, and XYN2 on plasmid pET-28a. 


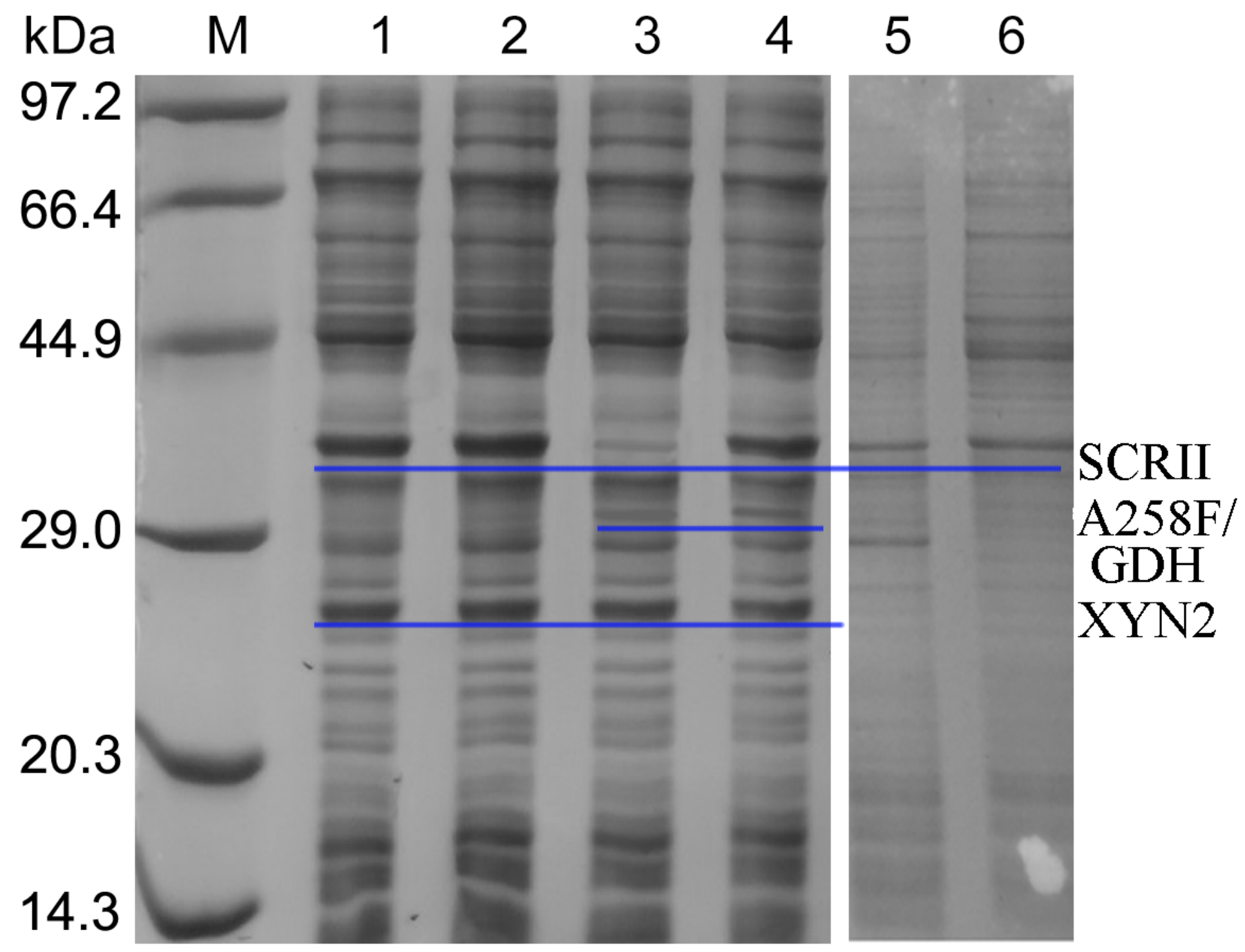

Figure 3

SDS-PAGE analysis of protein expression. M. Protein marker. The cell-free extracts of E. coli/pET-S-G-2 (Lane 1), E. coli/pET-S-2-G (Lane 2), E. coli/pET-G-2-S (Lane 3), E. coli/pET-G-S-2 (Lane 4), E. coli/pET-28a (Lane 5) induced with $0.1 \mathrm{mM}$ IPTG; lane 6. E. coli/pET-G-S-2 without induction. 


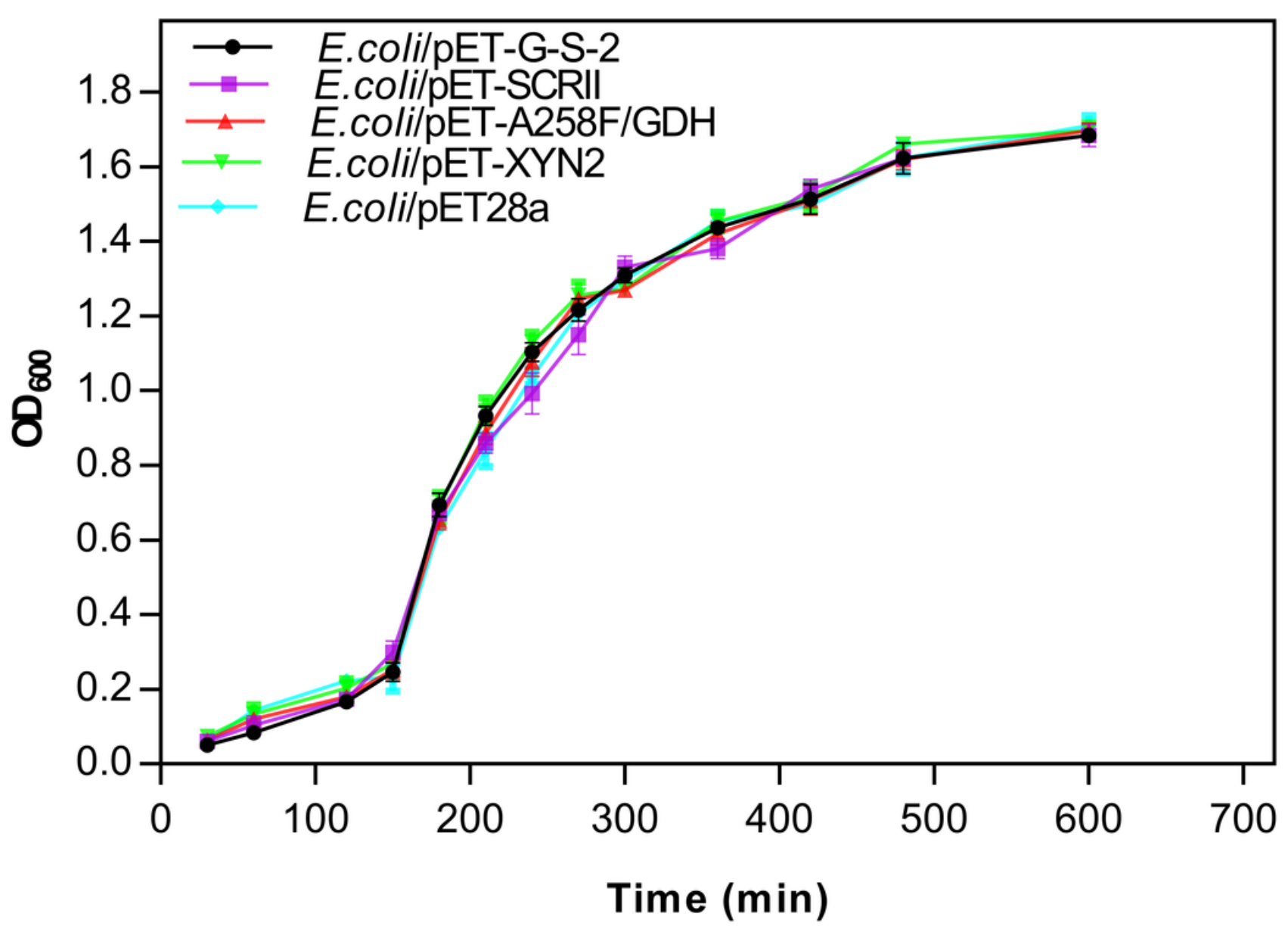

Figure 4

Cell-growth curve of the recombinant strains. The recombinant strains were cultured at $37^{\circ} \mathrm{C}$ in $500 \mathrm{~mL}$ flask bottles, with an initial working volume of $150 \mathrm{~mL}$, and then $0.1 \mathrm{mM}$ IPTG was added at $3 \mathrm{~h}$ to induce protein expression. The induction temperature is $25^{\circ} \mathrm{C}$. 


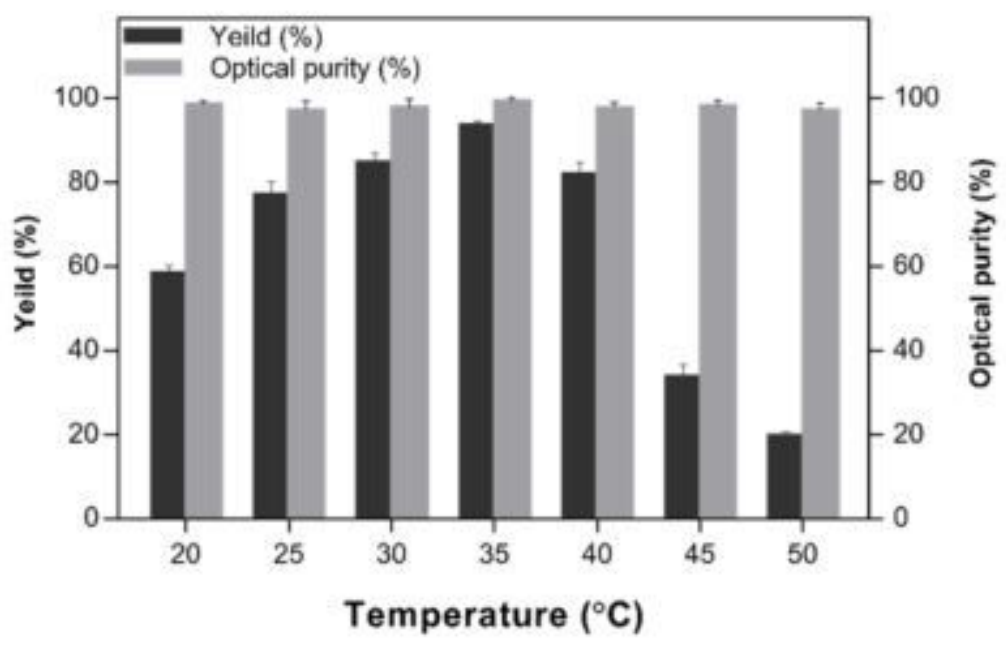

B

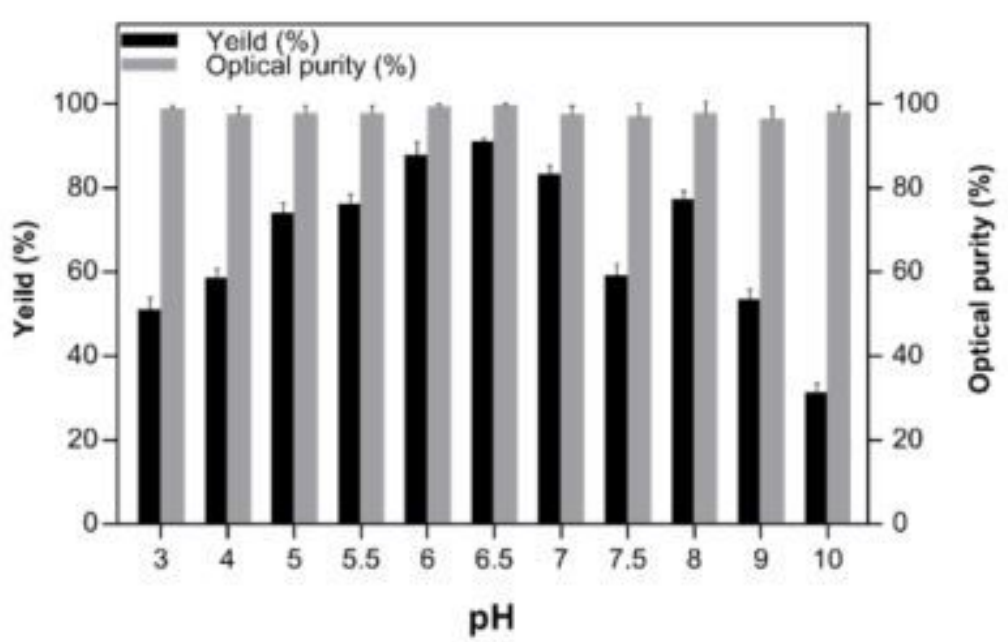

Figure 5

The effects of temperature (a) and pH (b) on E. coli BL21/pET-G-S-2 catalyzing 2-HAP biotransformation. The temperature optimum of 2-HAP transformation was determined at various temperatures (20-50 oC). The $\mathrm{pH}$ optimum of 2-HAP transformation was determined between $\mathrm{pH} 3.0$ and 10.0 using $0.1 \mathrm{M}$ citric acid buffer ( $\mathrm{pH} 3.0,4.0,5.0,6.0,6.5), 0.1 \mathrm{M}$ potassium phosphate buffer $(\mathrm{pH} 6.5,7.0,7.5)$, and $50 \mathrm{mM}$ Tris- $\mathrm{HCl}$ buffer (pH 8.0, 9.0, 10.0). 


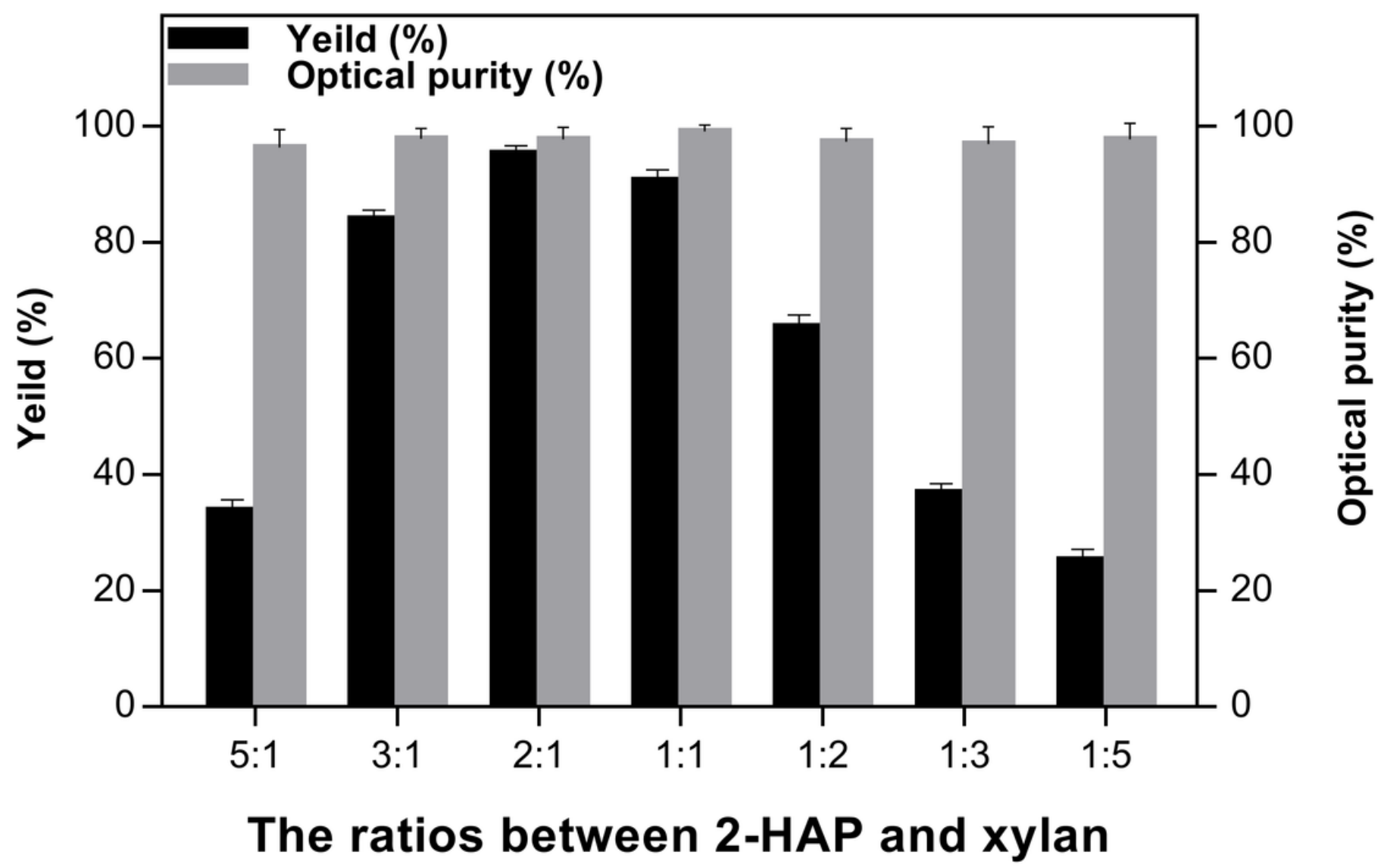

Figure 6

Optimization of the ratio between 2-HAP and xylan for (S)-PED biotransformation by the whole-cells of E. coli/pET-G-S-2. 


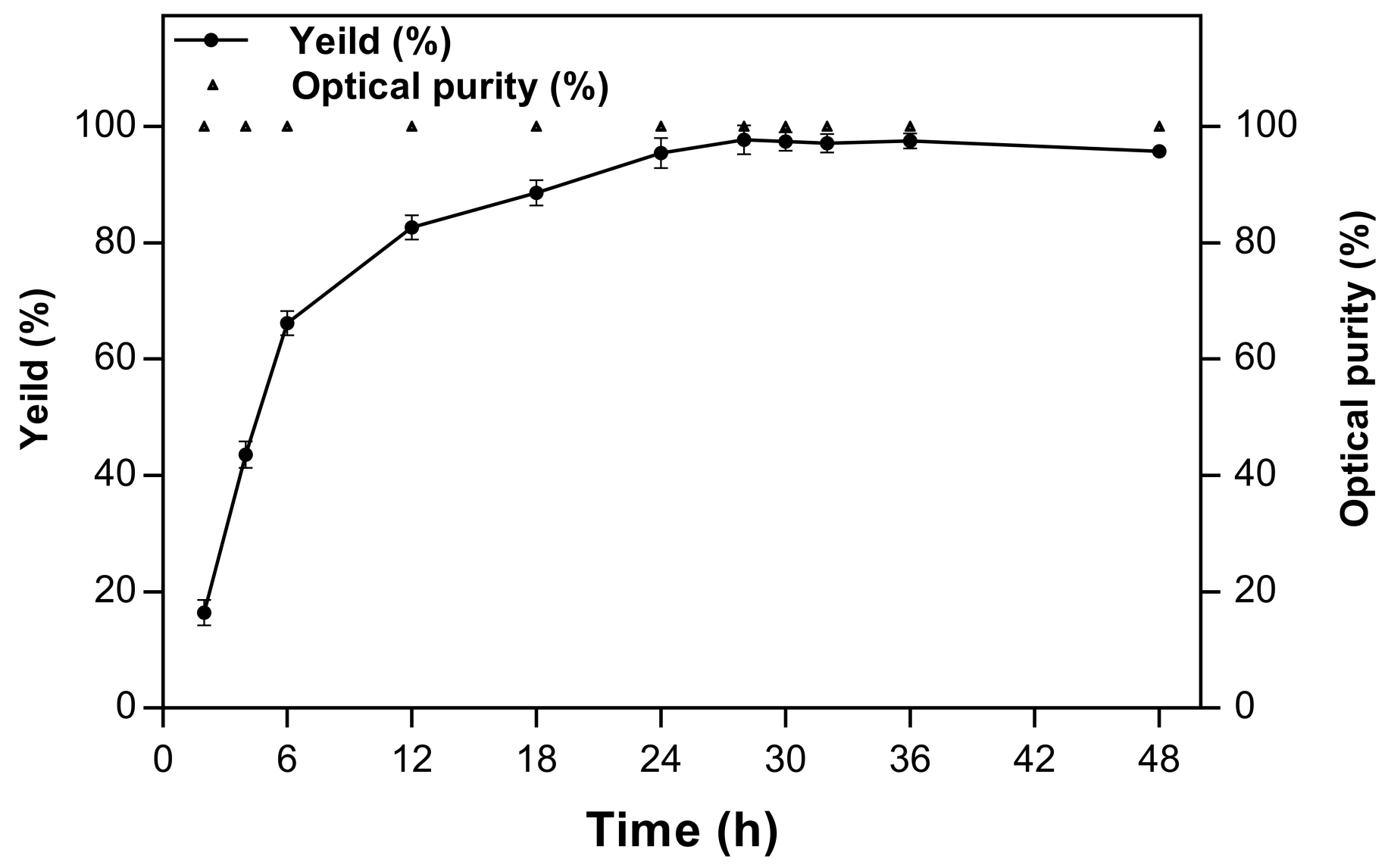

Figure 7

Time courses of biotransformation of 2-HAP to (S)-PED by the whole-cells of E. coli/pET-G-S-2. The enantioselective reaction was performed under optimal conditions: $\mathrm{pH} 6.5$ and $35^{\circ} \mathrm{C}$. 